\title{
PROCEDIA
}

DOI: 10.23888/humJ20214443-456

\section{THE LEFT-HAND DENTAL STUDENTS}

\section{Othman Abbas}

врач-стоматолог общей практики, ассистент кафедры ортопедической стоматологии и ортодонтии, РязГМУ им. акад. И.П. Павлова

\section{RYAZAN STATE MEDICAL UNIVERSITY}

\section{The left-hand dental students}

Othman Abbas(Lebanon) 
СЕТЕВОЙ НАУЧНЫЙ ЖУРНАЯ «ДИЧНОСТЬ В МЕНЯЮЩЕМСЯ МИРЕ: ЗДОРОВЬЕ, АДАПТАЦИЯ, РАЗВИТИЕ» www.humjournal.rzgmu.ru / E-mail: humjournal@rzgmu.ru

\section{Abstract:}

The purpose of this study was to evaluate the difficulties faced by LH students of dental faculty and the effect of their training program on the musculo-skeletal system. A survey of 11 questions was used to get the necessary data for further analysis. The results of the study showed that the percentage of LH students in the faculty is $\mathbf{7 . 3 2}$ percent (40 of $\mathbf{5 4 6}$ ). The prevalence of left-handedness of males $\mathbf{( 9 . 5 9 \% )}$ ) is higher than that of females $(6.03 \%)$. The majority of LH students (85\%) confirmed that their sinistrality is of no significance in their life organization. LH students neglect that their sinistrality has a significant effect on their dental practice, this is due to their limited experience in practice. The majority of the LH students (85\%) prefer using special dental units designed to fit their needs. $35 \%$ of the students approved that they started experiencing symptoms of MSDs during their practical phase of studies. The results of this study suggest that LH dental students require special educational atmosphere which would yield in a more professional undergraduatés with high efficiency in the work field.

Keywords: left-handness, dental students, dental practice,

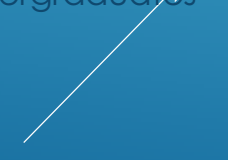

\section{Inroduction:}

In the modern industry, tools and products in general are manufactured in such a way to fit the biggest portion of the population in order to have a bigger market to sell the manufactured products, and when talking about handedness; this would be the right handed population since roughly $90 \%$ of the healthy adult population prefer using their right hand for manual actions [1, 2, 3, 4, 5] ,For this particular reason left-handers suffer from some professional problems, especially in the professions

that require manual skills to fulfill the needed tasks. The number of left- handed population has reached 15 percent of the global population, and about 17 mition of Russia's total population were recorded to be left- handers by august, 2013 (Left Gift, RIA News, 2013) and since dentistry is one of the demanding professions requiring concentration, precision, and skills [6]; dentists suffer from diffjeulties in the 
СЕТЕВОЙ НАУЧНЫЙ ЖУРНАЯ «ДИЧНОСТЬ В МЕНЯЮЩЕМСЯ МИРЕ: ЗДОРОВЬЕ, АДАПТАЦИЯ, РАЗВИТИЕ» www.humjournal.rzgmu.ru / E-mail: humjournal@rzgmu.ru

As a matter of fact, the difficulties dentists suffer during practice originate from the way this medical field is taught. In dental schools, dental procedures, techniques, chairs, and stations are designed mainly for the Right-Handed students $[7,8]$.

Dental practice can be a risk factor to work-related musculoskeletal disorders (MSD) which is manifested by pain in the neck, shoulder, upper and lower back, and less commonly in the arms, hands and wrists. This is due to the seating positions, hand and neck postures taken by the dentist and the accompanying muscular contractions. For a left-handed dentist, the seating positions can be less comfortable especially due to the unit standard design, increasing the risk of MSD due to the continuous contracture of muscles in the lower and upper back. This was the reason why few manufacturing companies started designing dental ynits for the left-handed dentists, or units that can be shifted from right to left handed mode, such as the Planmeca Compact- i3.
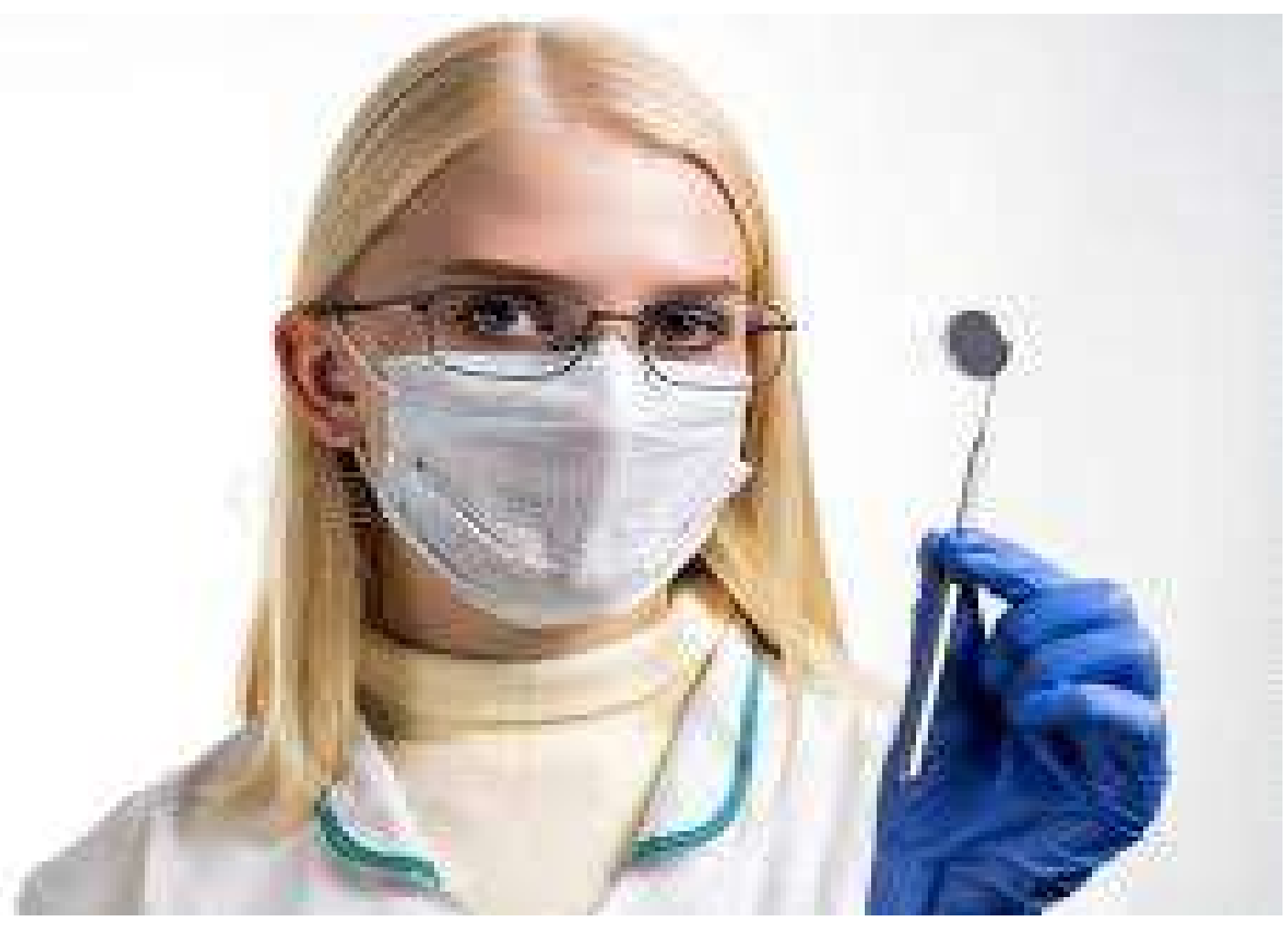


\section{Aim:}

The aim of this study is to investigate the difficulties faced by left- handed dental students during their clinical training phase and the disorders of the musculoskeletal system that they might have as complications to the use of instruments and equipment during their practice. In this given article, left-handed students of Ryazan State Medical University were the subject of the experimental study as an example of any dental students.

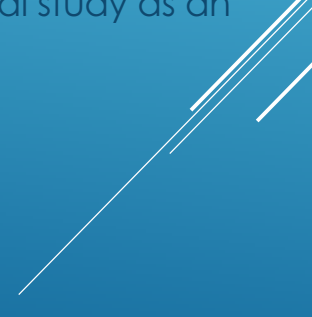

\section{Tasks:}

1) Conduct a psych diagnostic research using survey to study the difficulties faced the left hand dental students during the clinical practice.

2) Analyze the results using mathematical methods.

3) Draw conclusions regarding the results obtained.

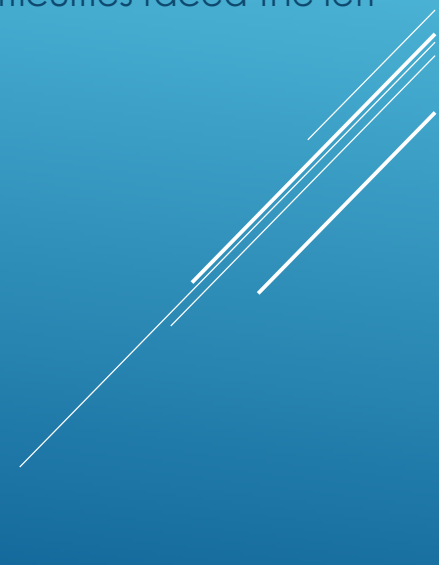


СЕТЕВОЙ НАУЧНЫЙ ЖУРНАЯ «ДИЧНОСТЬ В МЕНЯЮЩЕМСЯ МИРЕ: ЗДОРОВЬЕ, АДАПТАЦИЯ, РАЗВИТИЕ» www.humjournal.rzgmu.ru / E-mail: humjournal@rzgmu.ru

\section{Materials and methods:}

a survey of 11 questions was made and distributed among left-handed undergraduate and postgraduate students of Ryazan State Medical University named after Ivan P. Pavlov. 40 left-handed students participated and filled the given questionnaire, which was made on a computer program form and had 3 languages of choice (English, French and Russian) for foreign students to be able to participate. Their participation was essential to make sure that different cultural behaviour does not affect the results of the research done, while if done only for Russian citizens for instance, we could not be sure that certain cultural behaviours have been the reason behind deviating the results of the given research.

The computer program we have designed (certified and registered within the Russian Federal Service of Intellectual Property under the number 2021619643) [9] included an initia I part where the participant had to enter his/her age and gender.
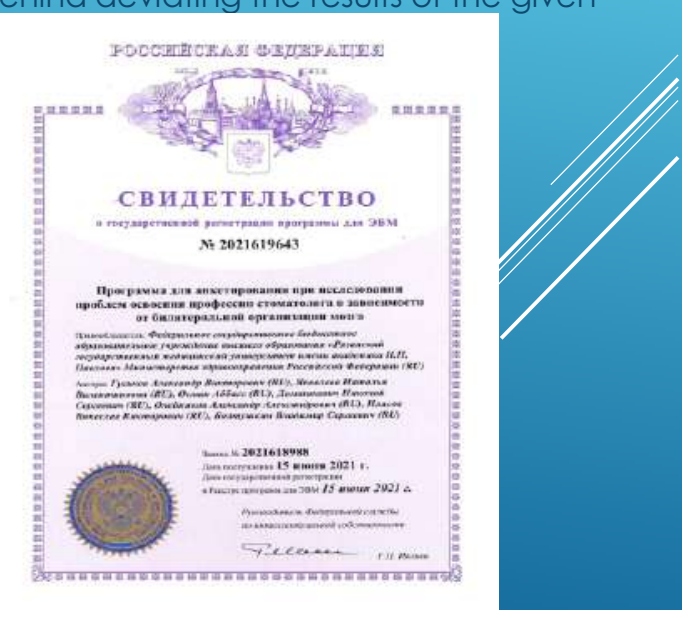

The survey questions were checked and revised by academic colleagues of the department of general and special psychology at the Ryazan State Medical University.

The questions asked included: difficulties while fulfilling dental procedures as a lefthanded, difficulties understanding the procedures being explained by a right-handed teacher, if they prefer the use of a dental unit made especially for left-handed dentists and if they ever used it and are they able to use the usual dental units made for righthanded dentists, if they face difficulties working with a right-handed assistant, 
СЕТЕВОЙ НАУЧНЫЙ ЖУРНАЯ «ДИЧНОСТЬ В МЕНЯЮЩЕМСЯ МИРЕ: ЗДОРОВЬЕ, АДАПТАЦИЯ, РАЗВИТИЕ» www.humjournal.rzgmu.ru / E-mail: humjournal@rzgmu.ru

and if they feel a psychological reaction from the patient side because of their sinistrality, and do they have to state down their condition while applying for a job

Our research was done in three steps: in step 1, we used social media platforms (instagram, facebook and vkontakte) to publish posts asking left-handed dentistry students to send their contact information for research within the department.

In step 2, we excluded students who are left handed due to medical conditions such as paralysis, trauma etc. because the acquired condition of such individuals will lead to non-accurate answers and thus wrong results (according to our colleagues in the psychology department). And the Index of left/right-handedness was used to assure that all our subject participants are true left-handed [10].

In step 3, we were supposed to contact the participating students to the departmenty and ask them to fill the survey on our local computers, but since the research was made in 2020, and due to the CoVid-19 pandemic, we found it much easier and// convenient to send our participants a link to our program using internet services, each participant had to open the link and fill the survey at home without any need to have physical contact with others, and thus not violating the prophylactic measures suggested by the Russian Ministry of Public Health.

\section{Results:}

$\mathbf{4 0}$ students were qualified to step $\mathbf{3}$ of our research, considering a total of $\mathbf{5 4 6}$ students in the faculty of dentistry within Ryazan State medical University, meaning only $\mathbf{7 . 3 2 \%}$ left-handed students within the faculty. In gender analysis, 21(52.5\%) LH participants were females and $\mathbf{1 9}(\mathbf{4 7 . 5 \% )}$ were males which makes are genders almost equal in our studied group, but being compared to the gender composition of the whole faculty where 348 students are females and 198 are males, a significant difference is noticed in the percentage of the left handed participants among thei gender count where LH females contribute in $\mathbf{6 . 0 3 \%}$ of the total female students LH males in $9.59 \%$ of their 21.45 years (standard deviation $=1.88$ ). 
СЕТЕВОЙ НАУЧНЫЙ ЖУРНАЯ «ДИЧНОСТЬ В МЕНЯЮЩЕМСЯ МИРЕ: ЗДОРОВЬЕ, АДАПТАЦИЯ, РАЗВИТИЕ» www.humjournal.rzgmu.ru / E-mail: humjournal@rzgmu.ru

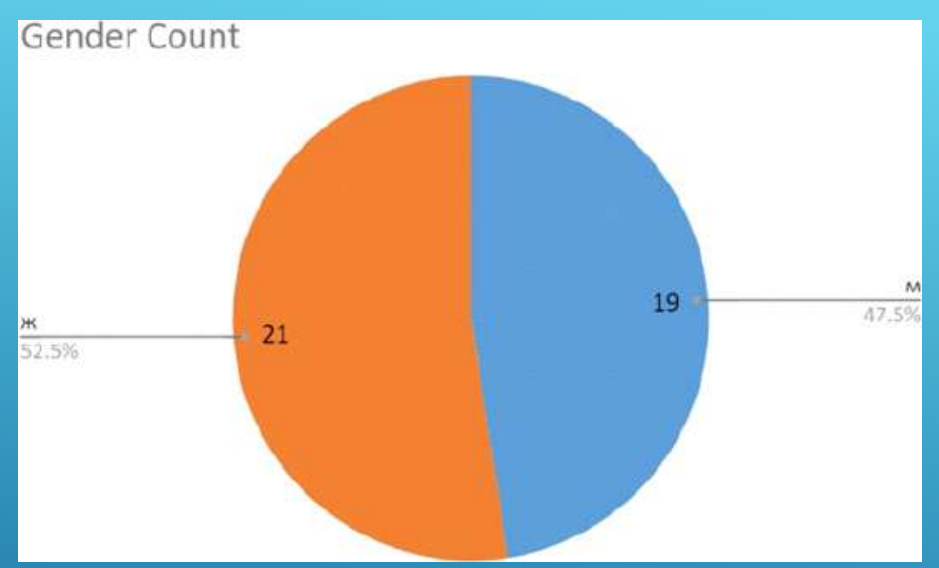

Figure 1. Pie-chart showing gender distribution of the left-handed students participating in the study.

\begin{tabular}{|l|l|l|l|}
\hline Question & Yes & No & $\begin{array}{l}\text { didn't think } \\
\text { about it }\end{array}$ \\
\hline $\begin{array}{l}\text { 1. Does your left-handedness bring } \\
\text { additional difficulties in your life? }\end{array}$ & $9(22.5 \%)$ & $\begin{array}{l}28 \\
(70 \%)\end{array}$ & $3(7.5 \%)$ \\
\hline $\begin{array}{l}\text { 2.Do you have any problems with } \\
\text { perform ing dental procedures due to } \\
\text { that you are left-handed? }\end{array}$ & $5(12.5 \%)$ & $\begin{array}{l}27 \\
(67.5 \%)\end{array}$ & $8(20 \%)$ \\
\hline $\begin{array}{l}\text { 3. Do you have problem s with the } \\
\text { development of professional skills } \\
\text { if they are demonstrated by right- } \\
\text { handed instructors (teachers)? }\end{array}$ & $6(15 \%)$ & $\begin{array}{l}15 \\
(37.5 \%)\end{array}$ & $19(47.5 \%)$ \\
\hline $\begin{array}{l}\text { 4. Does the training equipment on } \\
\text { which you acquire professional } \\
\text { skills allow you to consider that you } \\
\text { are left-handed? }\end{array}$ & $8(20 \%)$ & $\begin{array}{l}23 \\
(57.5 \%)\end{array}$ & $9(22.5 \%)$ \\
\hline $\begin{array}{l}5 . \text { Would you prefer to use a dental } \\
\text { chair, unit or station designed } \\
\text { specifically for a left-handed } \\
\text { dentist? }\end{array}$ & $34(85 \%)$ & $4(10 \%)$ & $2(5 \%)$ \\
\hline $\begin{array}{l}\text { 6. When applying for a job, do you } \\
\text { have to indicate on your resume } \\
\text { that } \\
\text { you are a left-handed dentist? }\end{array}$ & $7(17.5 \%)$ & $8(20 \%)$ & $25(62.5 \%)$ \\
$\begin{array}{l}7 . \text { W ill you retrain your children if } \\
\text { they demonstrate the habit of } \\
\text { usingthe left hand? }\end{array}$ & $5(12.5 \%)$ & $\begin{array}{l}34 \\
(85 \%)\end{array}$ & $1(2.5 \%)$ \\
\hline $\begin{array}{l}\text { 8.Can a left-handed dentist have } \\
\text { health problems (disorders of the } \\
\text { musculoskeletal system, etc.) if } \\
\text { he } \\
\text { uses professional equipment } \\
\text { thatits features? }\end{array}$ & $14(35 \%)$ & $\begin{array}{l}10 \\
(25 \%)\end{array}$ & $16(40 \%)$ \\
\hline
\end{tabular}




\begin{tabular}{|l|l|l|l|}
\hline Question & Yes & Sometimes & No \\
\hline $\begin{array}{l}\text { 9. Can you use devices } \\
\text { made for right-handed } \\
\text { dentists effectively? }\end{array}$ & $\begin{array}{l}19 \\
(47.5 \%)\end{array}$ & $21(52.5 \%)$ & 0 \\
\hline $\begin{array}{l}\text { 10. Will a left-handed } \\
\text { dentist have problems } \\
\text { working with a right- } \\
\text { handed assistant? }\end{array}$ & $6(15 \%)$ & $18(45 \%)$ & $16(40 \%)$ \\
\hline $\begin{array}{l}\text { 11. Do you think the } \\
\text { patient feels } \\
\text { uncomfortable while } \\
\text { being treated by a left- } \\
\text { handed dentist? }\end{array}$ & 0 & $4(10 \%)$ & $36(90 \%)$ \\
\hline $\begin{array}{l}\text { Table 2. last three questions of the survey on the basis of } \\
\text { agree/disagreeand sometimes. }\end{array}$ \\
\hline
\end{tabular}

\section{Discussion:}




\section{Prevalence (frequency) of the problem:}

Firstly, comparing the left-handedness of males and females among their genders showed a higher occurrence within males (9.59\%) compared to females (6.03\%), proving that males are more likely to be left-handed than females; which was confirmed by a meta-analysis of $\mathbf{1 4 4}$ studies done by psychologists in the University of Oxford [1 1].

\section{Significance of left-handedness in life organization:}

In question number 1 we noticed that only one fourth of the LH students approved that their sinistrality brings them additional difficulties in general while the majority of two thirds refused this fact. In more approval to the previously discussed question, came the results of question $\mathbf{7}$, where $\mathbf{8 5 \%}$ of the participants refused that they might retain their children if they demonstrate the habit of using their left hand, this indicates that they feel no difficulties in their lives being left-handed.

Figure 2

Does your left-handedness bring additional difficulties in your life? question 1

Figure 3

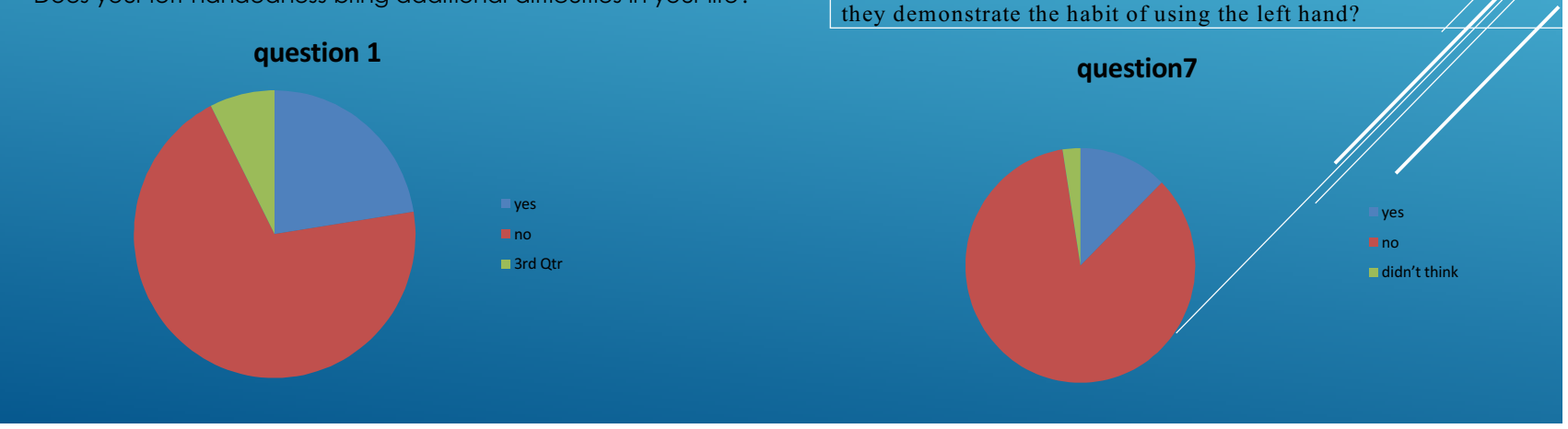


СЕТЕВОЙ НАУЧНЫЙ ЖУРНАЯ «ДИЧНОСТЬ В МЕНЯЮЩЕМСЯ МИРЕ: ЗДОРОВЬЕ, АДАПТАЦИЯ, РАЗВИТИЕ» www.humjournal.rzgmu.ru / E-mail: humjournal@rzgmu.ru

\section{Significance of left-handedness in education:}

Research results showed that when asked about performing dental procedures in question 2, the number of students agreeing to face difficulties decreased to one eighth of the total compared to results of question number 1, Which disagrees with the results concluded by Henderson et al. [12] which showed an increase. We believe that this contradiction is because our participants are undergraduate students and have less experience with dental procedures, their answers are consistent with the little experience and understanding to the difficulties they might start facing after graduation and practicing on a daily basis.

In question 3, half of the participants didn't think about the laterality of the instructor being right-handed and one third disagreed with the question, this means that it's not a fundamental issue for left-handed student to coupe with a right-handed instructor because they are used to coupe with teachers, who are more likely to be right-

handed, in schools since childhood.

Education neglects the problems of left-handed students, since the major part of the material in the educational process is presented theoretically and little experience does not allow them to understand the depth of the problem they will face jín practice.

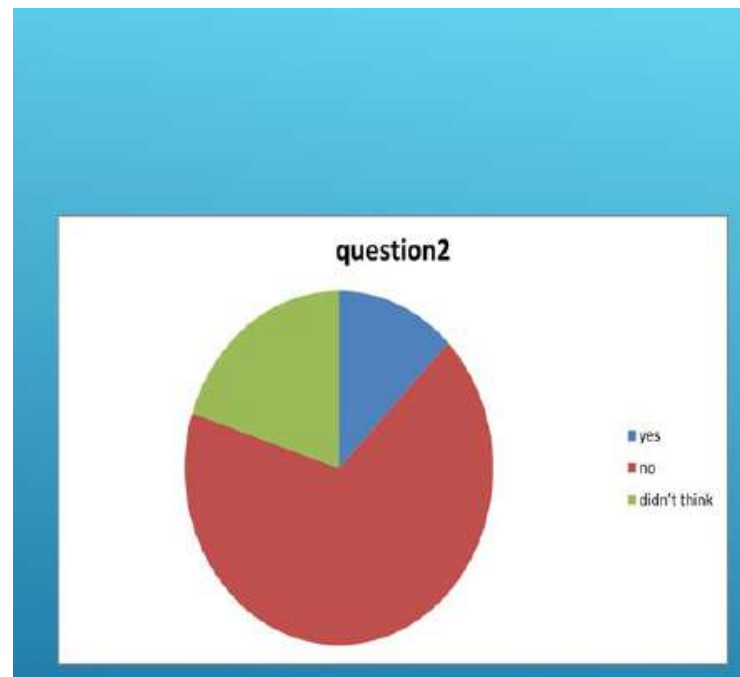

Figure 4. Do you have any problems with performing dental procedures due to that you are left-handed?

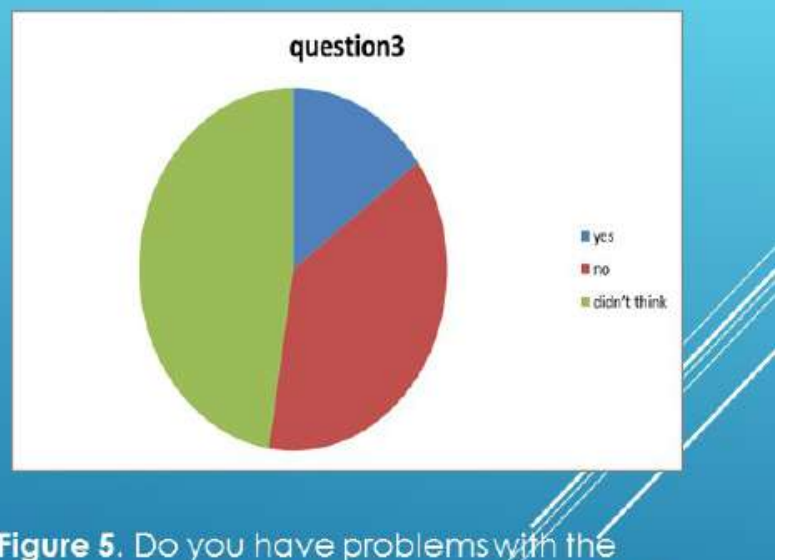

Figure 5. Do you have problems with the development of professional skilis if they are demonstrated by right-hand. 


\section{The role of left-handedness in the development of professional experience:}

Half of our participants disagreed with question 4, and almost the same percentage showed doubts when asked in question 9 , these results show that left-handed dental students face difficulties using standard dental equipment and devices. Moreover, 85\% approved in question 5 that they would prefer using dental units designed specifically for a left-handed dentist, which is consistent with the results of Kaya and Orbak that showed that $85.7 \%$ of dental students feel uncomfortable using right- handed dental chairs [7]. and reconfirmed with $84.5 \%$ by Sulieman 5 Al-Johany [13].

As responses to questions 10 and 11 , almost half refused having issues with the assistant being right handed and half had doubts, while almost all the students assured that patients won' uncomfortable because of their sinistrality. Psychology of left-handed individuals pushes them to maintain their identity as left-handers especially while dealing with other individuals sugf patients and assistants where they tend to hide their struggle, a strategy known as se identification with left- handedness" explained by the study of Yusra Masud and M. Asir Ajmal. [14]. This brings us to the answer of question 6 , where two thirds of left- handed stydents checked that they never thought about the need to indicate their sinistrality on their resume, approving the studies which showed that left-handers have an identity that may play a yital role in
maintaining high self-esteem [14].

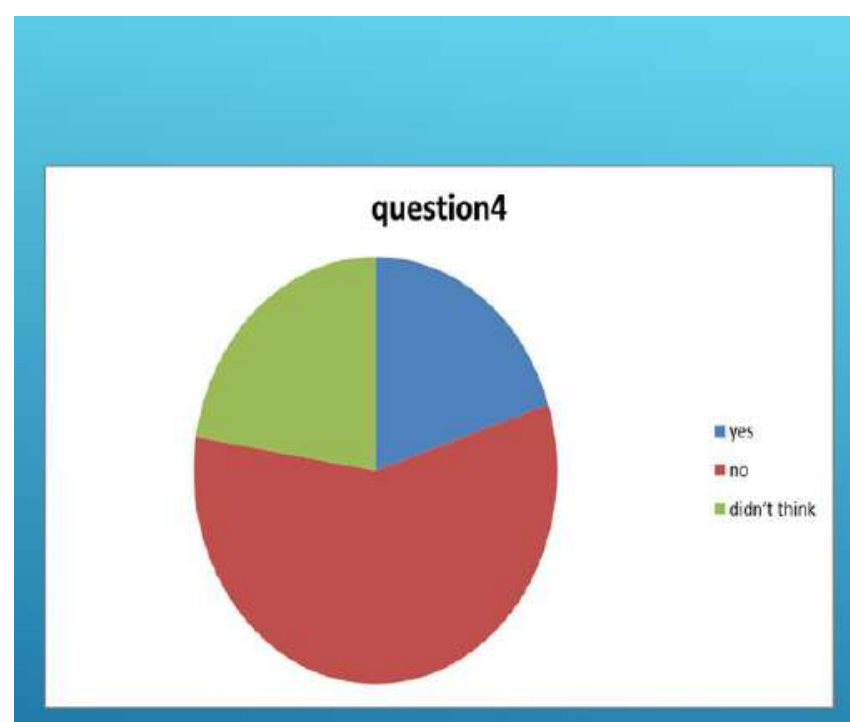

Figure 6. Does the training equipment on which you acquire professional skills allow you to consider that you are left-handed?

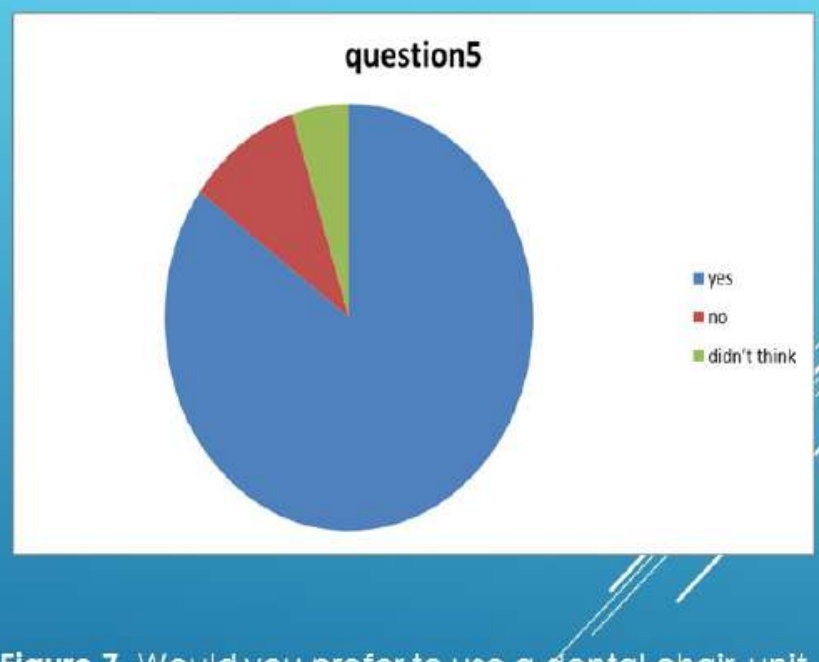

Figure 7. Would you prefer to use a dental chair, unit or station designed specifically for a left-handed 
СЕТЕВОЙ НАУЧНЫЙ ЖУРНАЯ «ДИЧНОСТЬ В МЕНЯЮЩЕМСЯ МИРЕ: ЗДОРОВЬЕ, АДАПТАЦИЯ, РАЗВИТИЕ» www.humjournal.rzgmu.ru / E-mail: humjournal@rzgmu.ru

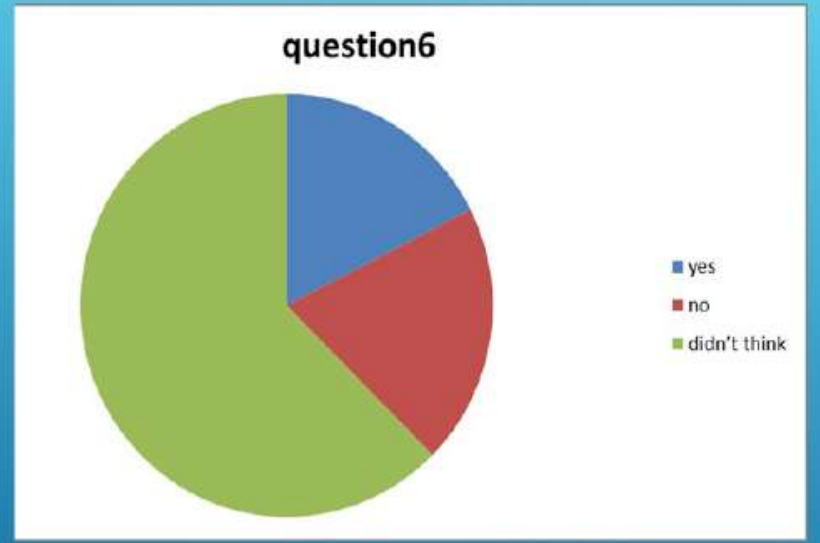

Figure 8. When applying for a job, do you have into dicate on your resume that you are a lefthanded dentist?

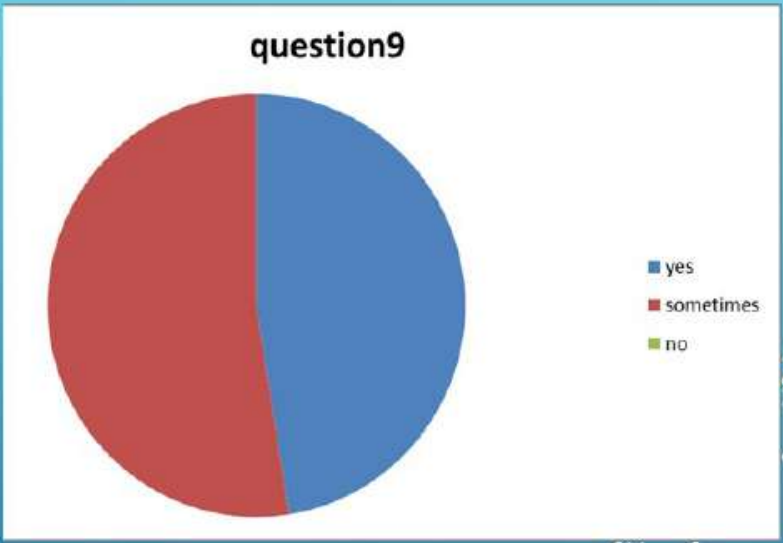

Figure 9. Can you use devices made for righthanded dentists effectively?

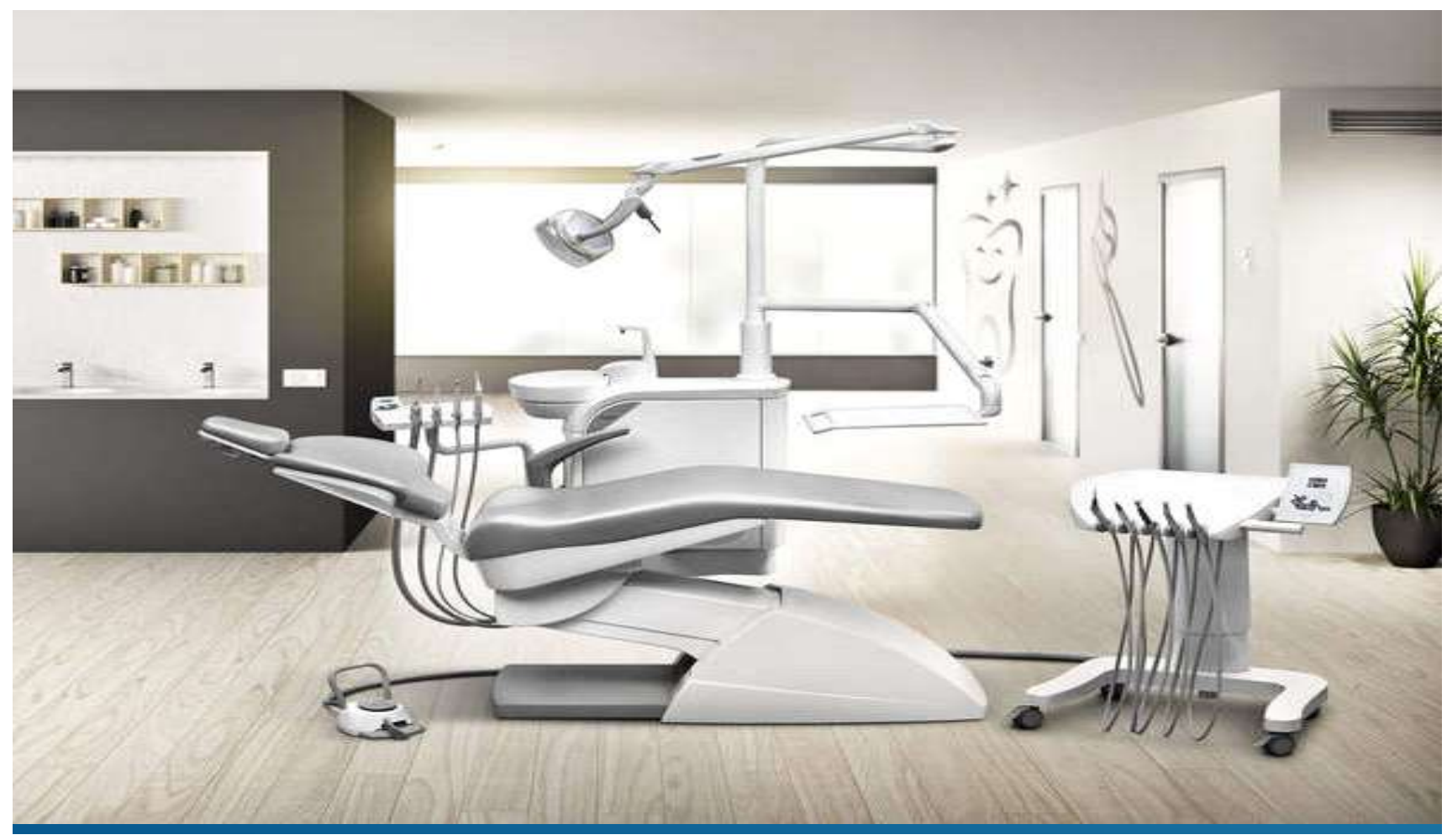




\section{-The significance of left-handed practice in dentistry on the musculo- skeletal system of the practitioner:}

Research showed that $\mathbf{4 0 \%}$ of the left-students are not aware of the risk

of having musculo-skeletal disorders, compared to $35 \%$ who approved that their practice Can affect their health status. Again, we believe that during the educational process, its diffieult to estimate the prevalence of the disorder because students have a limited practice experience. Even though, it's important to mention that one third of the left-handed students aldeady started facing symptoms of MSDs which indicates that left-handers are in the risk area of MSDs.

\section{Conclusion:}

Research has shown that difficulties in practicing dentistry for left- handers as well as symptoms of musculo-skeletal disorders exist. It is less relevant during theoretical semesters; which includes the first and second years of education in the faculty of dentistry, its relevance increases in semesters of practical training starting from the third educational year. It is necessary to develop special manipulation techniques for left-handed people and to master special equipment. All this will allow lefthanders to successfully professionalize and achieve high efficiency by the end of educational training at the university. 
СЕТЕВОЙ НАУЧНЫЙ ЖУРНАЯ «ДИЧНОСТЬ В МЕНЯЮЩЕМСЯ МИРЕ: ЗДОРОВЬЕ, АДАПТАЦИЯ, РАЗВИТИЕ» www.humjournal.rzgmu.ru / E-mail: humjournal@rzgmu.ru

1. Cavill, S. Development of handedness: comparison of questionnaire and performance- based measures of preference. /Cavill, S Bryden, P. Brain Cogn. (2003). 53, 149-151. doi: 10.1016/S0278-2626(03)00098-8

2. Adamo, D. E.. Establishing hand preference: why does it matter? /Adamo, D. E Taufiq, A Hand(2011) .6, 295-303. doi: 10.1007/s11552-011-9324-X

- 3. Ooki, S.. An overview of human handedness in twins. / S. Ooki, Front. Psychol(2014). 5:10. doi: 10.3389/fpsyg.2014.00010

- 4. Scharoun, S. M. Hand preference, performance abilities, and hand selection in children. /Scharoun, S. M Bryden, P. J Front. Psychol. (2014). 5:82. doi: 10.3389/fpsyg.2014.00082

- 5. Willems RM, Van der Haegen L, Fisher SE, Francks C. On the other hand: including left-handers in cognitive neuroscience and neurogenetics. Nat Rev Neurosci. 2014;15(3):193-201.

- 6. Tezel A, KavrutF, Tezel A, Kara C, Demir T, Kavrut R. Musculoskeletal disorders in left-and right-handed Turkish dental students. Int J Neurosci. 2005; $115(2)$ :255-266. doi:10.1080/00207450590519517

- 7. Kaya M.. Performance of left-handed dental students is improved when working from the left side of the patient./ Kaya M. Orbak. R. Int J Ind Ergon 2004:33:387-93

8. Graham RM. Left handed GDP's and students. Br Dent J. 1995;178(9):326.

- 9. Гуськов А. В. Яковлева Н.В., Осман А. АОмашкевич Н.С. Олейников А. А. Илясов В. В., Болтушкин В.С. Программа Аля анкетирования при исслеАовании проблем освоения професссии стоматолога в зависимости от билатеральной организации мозга, Программа Аля ЭВМ №2021619643 опубл. 15.06.2021.

- 10. Пятых И. К. Психометрический анализ теста "Индекс ғ

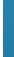

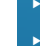

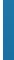

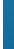

$\bullet$

СВЕДЕНИЯ ОБ АВТОРАХ:

Осман Аббасс - врач-стоматолог общей практики, ассистент кафедры ортопедической стоматологии и ортодонтии, Рязанский государственный медицинский университет имени академика И.П.Павлова; 390026, Рязань, ул. Высоковольтная, д. 9. E-mail: abbasothman@mail.ru

INFORMATION ABOUT AUTHORS:

Othman Abbas - general dental practitioner, teacher at the Department of Orthopedic Dentistry and Orthodontics; 9, Vysokovoltnaya str., 390026 Ryazan. E-mail: abbasothman@mail.ru

Дата поступления / Paper received: 06.09.2021.

Дата принятия в печать / Paper accepted: 1.12.2021.

\section{для цитИРовАния:}

Othman A. The left-hand dental students // Личность в меняющемся мире: здоровье, адаптация, развитие. 2021. Т. 9, № 4 (35). С. 443-4 Доступно по: http://humjournal.rzgmu.ru/art\&id=508. Ссылка активна на чч.мм.гггг. doi: 10.23888/humJ20214443-456

\section{FOR CITATION:}

Othman A. The left-hand dental students. Personality in a changing word: health, adaptation, development. 2021;9(4):443-56. Available at: http://humjournal.rzgmu.ru/art\&id=508. Accessed: dd Month yyyy. doi: 10.23888/humJ20214443-456 